\title{
Correction to: Bargaining strategies for governance complex games
}

\section{Daniel Verdier ${ }^{1}$}

Published online: 21 June 2021

(c) Springer Science+Business Media, LLC, part of Springer Nature 2021

\section{Correction to: The Review of International Organizations https://doi.org/10.1007/s11558-020-09407-9}

The article Bargaining strategies for governance complex games, written by Daniel Verdier, was originally published online on the publisher's internet portal on January 7, 2021 with Open Access under a "Creative Commons Attribution (CC BY) license 4.0".

With the author's/authors' decision to cancel Open Access the copyright of the article changed on June 3, 2021 to (C) The Author(s), under exclusive licence to Springer Science + Business Media, LLC, part of Springer Nature 2021 with all rights reserved.

The original article has been corrected.

Publisher's note Springer Nature remains neutral with regard to jurisdictional claims in published maps and institutional affiliations.

The original article can be found online at https://doi.org/10.1007/s11558-020-09407-9.

Daniel Verdier

verdier.2@osu.edu

1 Political Science, The Ohio State University, Columbus, OH, USA 